\title{
Exploring voltage output using a dye-sensitized solar cell
}

\author{
E. O. Osafile ${ }^{1}$, O. D. Ojuh ${ }^{2}$ \\ ${ }^{1}$ Department of Physics, Federal University of Petroleum Resources, Effurun, Nigeria \\ ${ }^{2}$ Department of Basic Sciences, Benson Idahosa University, Benin City, Nigeria
}

\section{Email address:}

eromopower@yahoo.com(E. O. Osafile)

\section{To cite this article:}

E. O. Osafile, O. D. Ojuh. Exploring Voltage Output Using a Dye-Sensitized Solar Cell. International Journal of Materials Science and Applications. Vol. 2, No. 3, 2013, pp. 120-123. doi: 10.11648/j.ijmsa.20130203.19

\begin{abstract}
A dye-sensitized solar cell consisting of two conducting glass electrodes in a sandwich arrangement was developed in the laboratory. Both electrodes were coated with tin dioxide after which the non conductive electrode was again coated with titanium dioxide. The titanium dioxide is designed to serve as an absorbent for the dye. The technology adopted in this paper is that the dye molecules absorb light, and produce excited electrons which in turn generate current in the output terminals of the cell. The dye regains its lost electron with the aid of the iodide electrolyte present in the cell. This work was done using the following light sources: fluorescent and overhead projector light. The voltages measured from each light source were separately documented. This paper shows that the solar cell exposed to the overhead projector light produced a voltage of between $1.3 \mathrm{v}$ and $1.5 \mathrm{v}$ while the voltage produced from the solar cell exposed to the fluorescent light was rather low. Cells made from raspberries, blackberries, spinach leaves, and grape fruit dyes were independently experimented on, and results showed that only cells made from the berries yielded reasonable quantity of electrons. This is because they have the right chemical composition and the energy band required to bond with the titanium dioxide which enables the release of electrons when light falls on them. The dye sensitized solar cell is very attractive because the materials needed are not only available but also cheap. In this laboratory work, efficiency evaluation yielded about $14.3 \%$ for the blackberry dye-sensitized solar cell.
\end{abstract}

Keywords: Dye Sensitized Solar Cells, Titanium Dioxide, Voltage

\section{Introduction}

Solar energy is used for many technologies in our world today. Yet the level of efficiency is still relatively minimal. The individual microscopic use of solar energy use takes place on the nanometer scale. Solar energy can be utilized as solar electricity, solar fuel, solar thermal, and thermoelectricity. Several techniques are currently under investigation as to how to increase the efficiency of solar energy and simultaneously be cost effective. One wide spread technique for solar fuels is the biomass derived fuels. The current biomass primary energy supply is about $11 \%$ of the total energy demand of 13.3TW [1]. The major development areas for biomass-to-fuels are concerned with the production of liquid fuels such as ethanol, electricity, and co-produced heat. Gaseous fuel such as methane, fuel gas, synthetic-gas, and in the future, hydrogen. The United States of America has a major program to develop processes that co-produce energy and higher value products such as bio-refineries [2].
The large scale of the biomass and bio energy supply chain is set in a frame work of constraints with respect to the environment, food and fiber supply, and sustainability. Most of the biomass used in industrial countries is part of use, re-use and recycling of biomass materials with post consumer residues being very important. However, crops for energy are of growing importance such as sugar cane [3], cereals [4], and oil seeds [5] and are making significant inputs to the expanding liquid bio-fuel markets. These tend to be the most expensive biomass resources currently accounting for only a small proportion of the supply curve. The bio energy potential is a subject of much debate due to the limited land area and the competition that is perceived with the food and fiber sectors.

Ongoing research for solar thermal and thermoelectric is as yet inconclusive as to a method of increasing efficiency rate and cost. Solar electricity research has been largely carried out using photovoltaic technology with flat plates and concentrator options. An efficiency of about $21.5 \%$ with a long life time of about 20 years has been recently achieved [6]. However this technique is still relatively 
expensive, hence other approaches to having a cost effective and efficient solar electricity system like flat plate thin film, amorphous silicon, cadmium telluride, copper indium diselenide, polycrystalline thin film multi-junctions, are being currently explored. A key problem in optimizing the cost/efficiency ratio of such devices is that relatively pure materials are needed to ensure that the photo excited carriers are efficiently collected in conventional planar solar cell device designs. Other new technologies for solar electricity under investigation are dye- sensitized solar cells and nanotechnology solar cells. Dye-sensitized cells are nanoparticulate photovoltaic cells that mimic the photosynthetic process in solar to electricity conversion [7]

Progress in the field of solar energy heavily depends on the development of new tools for the characterization of matter and new theoretical tools. At the experimental level, one major goal is to create probes that reveal the structure and composition of nano-scale materials with atomic resolution. A second goal involves the development of tools that can be used to follow the complete flow of energy through each primary step of the solar conversion processes - from absorption [8,9] to charge transfer [10,11], harvesting, chemical conversion, and separation. The use of nanostructure such as mesoscopic dye-sensitized solar cell offers an opportunity to circumvent this key limitation, and therefore introduce a paradigm shift in the fabrication and design of solar energy conversion devices to produce either electricity or fuels. It is in this light that a fundamental experiment was carried out in the laboratory to aid the learning of how to build a dye-sensitized solar cell and understand its process of conversion of light to electrical energy. An exciting aspect of this approach is the generic concept of the nanostructured dye-sensitized solar cell that can be extended to a range of novel configurations involving different light absorbers, and electron hole conducting phases as was carried out in this work. A key property of the dye-sensitized nanostructured film is that since charge carrier pairs are generated only near the interface and are separated rapidly into two different phases, bulk recombination and semiconductor instability are avoided.

The purpose of this work is to familiarize ourselves with a technique that can surmount most of the problems that has been encountered using other methods on a larger scale. The dye-sensitized solar cell [12] has foundations in solid state physics and photochemistry. It is also called "Gratzel cell". In this concept, organic dye molecules are absorbed on a nanocrystalline titanium dioxide $\left(\mathrm{TiO}_{2}\right)$ film, and the nanopores of the film are filled with a redox electrolyte [13]. The dye absorbs photons to create an excited molecular state that can inject electrons into the titanium dioxide. The electrons percolate through the nanoporous titanium dioxide film and are collected at a transparent electrode. The oxidized dye is reduced back to the ground state by accepting electrons from the redox relay via ionic transport from a metal counter electrode, this completes the circuit and electrical power is generated in the external circuit. The low cost of the constituent material for building this cell, the potential simplicity of the building process, and the stability of the long lifespan makes it quite attractive. For example, $\mathrm{TiO}_{2}$ is a common material used in paints and tooth paste. An efficiency of $14.3 \%$ was achieved in this laboratory scale experiment, however light used were fluorescent and overhead projector lights. Hence it is expected that efficiency will be lower when photons are absorbed directly from sunlight except the photon capturing process is properly controlled. Furthermore, to enhance the amount of photon captured, the energy and chemical constituent of the dye used was evaluated based on standard photosynthetic properties.

The remaining part of the paper is structured as follows: the following section describes in details the experimental framework for building a dye sensitized solar. The results and the reasons for the results obtained are addressed in the next section. The paper concludes with the discussion of the findings in this preliminary work.

\section{Methodology and Experiment}

The materials required to build a dye-sensitized solar cell are relatively cheap, common, and largely non poisonous. In this work, $6 \mathrm{~g}$ of titanium dioxide was mixed with $9 \mathrm{ml}$ of acetic acid solution and the titanium dioxide paste produced was allowed to equilibrate for about 15 minutes, following which it was used to coat the non conductive side of the glass slide to a thickness of $200 \mu \mathrm{m}$, with an electrode active area of $1.5 \mathrm{~cm}$ by $2 \mathrm{~cm}$. The coated slide was aired to dry and thereafter set on a wire screen and placed on a ring stand. It was left to cool to room temperature after subjecting it to a Bunsen burner heat for about 10 minutes. The titanium dioxide coated slide was placed in a raspberry dye and allowed for about 10 to 15 minutes to enable the titanium dioxide absorb the dye completely, the coated slide was then rinsed with water followed by isopropyl to suck out all excess water stuck in the slide. The second coated slide was super-coated with graphite. The dry stained electrode and the graphite coated counter electrode were positioned such that the conductive sides faced each other. The exposed sides of the cell served as contact points for the positive and negative electrodes to ensure the extraction of electricity from the test cell. The cell was held together with binder clips. At this point the solar cell for this work has been completely built. With the lab pro attached computer connected to the voltage probe, the solar cell or panel is ready to get to work just by connecting the voltage probe to it. Over all, four different cells were constructed individually using raspberry dye, blackberry dye, spinach leave dye and grape fruit dye. A sample cell is shown in Figure 1 below. These cells were directly exposed individually, first to fluorescent light and afterwards to an overhead projector light and the voltage measurement recorded on the computer on each occasion. 


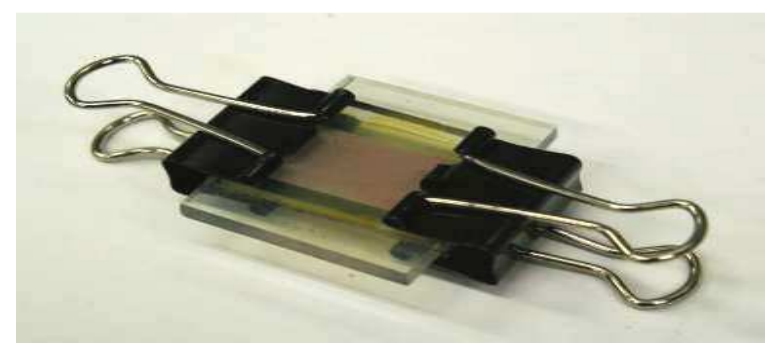

Fig 1. A sample clip bound dye-sensitized solar cell.

\section{Results}

From the laboratory experiment carried out at a fixed resistance of $250 \Omega$ and a measured intensity of $16 \mathrm{~mW} / \mathrm{cm}^{2}$ and $21 \mathrm{~mW} / \mathrm{cm}^{2}$ for fluorescent light and overhead projector light respectively, results obtained for the various dyes used when exposed to a direct overhead projector light are presented in Table1 while those obtained when exposed to a fluorescent light are presented in Table 2 .

Table 1. Results obtained for measured voltage output and calculated current produced for the dyes used with the solar cells was exposed to an overhead projector light.

\begin{tabular}{ccccc}
\hline Parameters & \multicolumn{4}{c}{ DYE } \\
\hline & Raspberry & Blackberry & $\begin{array}{c}\text { Grape } \\
\text { fruit }\end{array}$ & $\begin{array}{c}\text { Spinach } \\
\text { leaves }\end{array}$ \\
$\begin{array}{c}\text { Resistance } \\
(\Omega)\end{array}$ & 250 & 250 & 250 & 250 \\
Voltage $(\mathrm{v})$ & 1.30 & 1.50 & 0.4 & 0.3 \\
Current $(\mathrm{mA})$ & 5.20 & 6.00 & 1.6 & 1.2 \\
\hline
\end{tabular}

The intensity (power) of the incoming light from the overhead projector has been calculated from the outset to be $21 \mathrm{~mW} / \mathrm{cm}^{2}$. The area of the conductive glass slide coated with $\mathrm{TiO}_{2}$ is approximately $1.5 \mathrm{~cm}^{2} \times 2 \mathrm{~cm}^{2}=3 \mathrm{~cm}^{2}$.

Thus the power per unit area for the raspberry solar cell $\left(\mathrm{p}_{\mathrm{r}}\right)$ is calculated as:

$$
\mathrm{p}_{\mathrm{r}}=\underline{\mathrm{I}}_{\underline{r}} \underline{\mathrm{X} \mathrm{v}}_{\underline{\mathrm{r}}}=\underline{8.20 \times 1.30}=2.25 \mathrm{~mW} / \mathrm{cm}^{2}
$$

$$
\text { A } 3
$$

The cell to electricity conversion efficiency for raspberry $\left(\mathrm{E}_{\mathrm{r}}\right)$ is calculated as:

$$
\mathrm{E}_{\mathrm{r}}=\underline{2.25} \times 100 \%=10.71 \%
$$

Again, the power per unit area for the blackberry solar cell $\left(p_{b}\right)$ is calculated as:

$$
\mathrm{P}_{\mathrm{b}}=\underline{\mathrm{I}}_{\underline{\mathrm{b}}} \underline{\mathrm{X} \mathrm{v}}_{\underline{\mathrm{b}}}=\underline{6.00 \times 1.50}=3.00 \mathrm{~mW} / \mathrm{cm}^{2}
$$

The cell to electricity conversion efficiency for blackberry $\left(\mathrm{E}_{\mathrm{b}}\right)$ is calculated as:

$$
\mathrm{E}_{\mathrm{b}}=\underline{3.00} \times 100 \%=14.29 \%
$$

Also, the power per unit area for the grape juice solar cell $\left(\mathrm{p}_{\mathrm{g}}\right)$ is calculated thus:

$$
\mathrm{P}_{\mathrm{g}}={\underline{\mathrm{I}} \mathrm{g} \underline{\mathrm{X} \mathrm{v}}_{\mathrm{g}}=\underline{1.6 \times 0.4}}_{\mathrm{A}}=\begin{gathered}
0.21 \mathrm{~mW} / \mathrm{cm}^{2} \\
3
\end{gathered}
$$

The cell to electricity conversion efficiency for the grape juice $\left(E_{g}\right)$ is calculated as:

$$
\mathrm{E}_{\mathrm{g}}=\underline{0.21} \times 100 \%=1.00 \%
$$

Also, the power per unit area for the spinach leave solar cell $\left(\mathrm{p}_{\mathrm{s}}\right)$ is calculated as:

$$
\mathrm{P}_{\mathrm{s}}=\underline{\mathrm{I}_{\mathrm{s}}} \underline{\mathrm{XV}_{\underline{\mathrm{s}}}}=\underline{1.2 \times 0.3}=0.12 \mathrm{~mW} / \mathrm{cm}^{2}
$$

$$
\text { A } 3
$$

The cell to electricity conversion efficiency for the spinach leaves $\left(\mathrm{E}_{\mathrm{s}}\right)$ is calculated as:

$$
\mathrm{E}_{\mathrm{s}}=\underline{0.12} \times 100 \%=0.57 \%
$$

21

With the results for power and conversion efficiency for the overhead projector light obtained, the same procedure is carried out for the fluorescent light whose intensity is $16 \mathrm{~mW} / \mathrm{cm}^{2}$.

Table 2. Results obtained for measured voltage output and calculated current produced for the dyes used with the solar cell exposed to a fluorescent light.

\begin{tabular}{ccccc}
\hline Parameters & \multicolumn{4}{c}{ DYE } \\
\hline & Raspberry & Blackberry & $\begin{array}{c}\text { Grape } \\
\text { fruit }\end{array}$ & $\begin{array}{c}\text { Spinach } \\
\text { leaves }\end{array}$ \\
$\begin{array}{c}\text { Resistance } \\
(\Omega)\end{array}$ & 250 & 250 & 250 & 250 \\
Voltage $(\mathrm{v})$ & 0.15 & 0.18 & 0.05 & 0.02 \\
Current $(\mathrm{mA})$ & 0.60 & 0.72 & 0.20 & 0.08 \\
\hline
\end{tabular}

The results of the power and conversion efficiency for the various dyes are tabulated in Table 3.

Table 3. Results obtained for the power output and conversion efficiency for the dyes used with the solar cell exposed to a fluorescent light.

\begin{tabular}{ccccc}
\hline Parameters & \multicolumn{4}{c}{ DYE } \\
\hline & Raspberry & Blackberry & $\begin{array}{c}\text { Grape } \\
\text { fruit }\end{array}$ & $\begin{array}{c}\text { Spinach } \\
\text { leaves }\end{array}$ \\
$\begin{array}{c}\text { Power } \\
\left(\mathrm{mW} / \mathrm{cm}^{2}\right)\end{array}$ & 0.03 & 0.04 & 0.003 & 0.0005 \\
Efficiency & 0.19 & 0.27 & 0.02 & 0.003 \\
\hline
\end{tabular}

\section{Discussion of Results}

The dyes from the blackberries and raspberries produced voltages of $1.5 \mathrm{v}$ and $1.3 \mathrm{v}$ respectively with the light from the overhead projector used, while the voltages recorded using the spinach leave and the grape where rather insignificant. However, the voltage produced with the cell exposed to fluorescent light as shown in table 2 is noted to be significantly low. From research (8), the overhead projector has more light photons which give rise to a lot of 
photo-emissions, hence creating an environment for a higher voltage output. This is adduced to the fact that the overhead projector has a broader spectrum of light which is closer to the spectrum of the sun, than the fluorescent light which emits fewer frequencies of light and produces less energy in the cell. The theory of the dye-sensitized solar cell is close to that of the natural process of photosynthesis that makes use of the color pigment in plant for conversion [14]. Dyes extracted from berries recorded higher voltage because they were observed to have energies ranging from the visible band to the near infra red band and they also contain some cell wall materials such as cellulose and lignin as is equally found to be present in photosynthetic processes. The calculated efficiency of this laboratory work was about $14.3 \%$. It is however envisaged that if light harvesting is properly controlled, using direct sunlight will produce results with greater efficiency.

\section{Conclusion}

In this preliminary work, the voltage output was probed using a fixed resistance with different chemical composition of dyes. Considering the size of the solar cell, the voltage obtained is quite encouraging. Hence, work using dye-sensitized solar cells looks promising, attractive and has a lot of potentials because the materials are available and inexpensive, even as the building process is equally inexpensive. It can work effectively in low lighting like cloudy condition considering the result obtained despite the source of light used for this experiment. It is notably less susceptible to losing energy to heat, it also promises a long and stable life span because the conversion system of the cell is defect tolerant and self repairing. However caution has to be applied with respect to the chemical component and energy band of the dye used.

\section{References}

[1] International Energy Agency (IEA), World Energy Outlook 2004, IEA, Paris: Organization for Economic CoOperation and Development (2004).
[2] U.S. Department Of Energy (DOE) Biomass Program, Biomass Program Multiyear Multiple Plan, Washington, D.C. (2003). Available At Http://Devafdc.Nrel.Gov/Biogeneral/Program_Review/Myt p.Pdf.

[3] J. Goldenberg et al "Ethanol Learning Curve - The Brazilian Experience" Biomass and Bioenergy 26(3), 301304 (2004).

[4] A. Bullion, "Ethanol Trends," International Sugar Journal, CVI (1263), 173-174, 177 (2004).

[5] N. Martini and J.S. Schell (Eds.) Plant Oils as Fuels Present State of Science and Future Development. SpringerVerlag, ISBN 3-54-064754-6 (1998).

[6] W.P. Mulligan, D.H. Rose, M.J. Cudzinovic, D.M. De Ceuster, K.R.Mcintosh, D.D. Smith, and R.M. Swanson, In Proc. 19th European Photovoltaic Solar Energy Conf., June 7-11, 2004 (To be published).

[7] Reijnders, L. "Design Issues for Improved Environmental Performance of Dye-sensitized and Organic Nanoparticulate Solar Cells," Journal of Cleaner Production, 18(2010): 307312

[8] T. Trupke, M.A. Green and P. Wurfel, "Improving Solar Cell Efficiencies by Down-Conversion of High Energy Photons," J. Appl. Phys. 92, 1668 (2002a).

[9] S.M. Nie and S.R. Emery, "Probing Single Molecules and Single Nanoparticles by Surface-Enhanced Raman Scattering," Science 275, 1102 (1997).

[10] H. Wu, J.J. Ditmer, and A.P. Alivisatos "Hybrid Nanorod Polymer Solar Cells," Science 295, 2425 (2002).

[11] F.X. Redl, K.S. Cho, C.B. Murray, and S. O'brein, "ThreeDimensional Superlattices of Magnetic Nanocrystals and Semiconductor Quantum Dots," Nature 423, 968 (2003).

[12] B. O'regan and M. Gratzel, "A Low-Cost, High Efficiency Solar Cell Based on Dye -Sensitized Colloidal Tio2 Films" Nature 353,737 (1991).

[13] Institute for Chemical Education - Nanocrystalline Solar Cell Kit, University of Wiscousin - Madison. http://ice.chem.wisc.edu/ice.

[14] L. Fanis, "Nanocrystalline Solar Cell Kit Recreating Photosynthesis," ICE publication, pp52 (2010). 